\title{
PENINGKATAN KETERAMPILAN MEMBACA PERMULAAN DENGAN MEDIA KARTU KATA TEMA LINGKUNGAN BERSIH, SEHAT, DAN ASRI PADA SISWA KELAS 1 UPT. SD NEGERI 04 BARINGIN
}

\author{
ERNINENG SISWATI
}

erninengsiswati04@gmail.com

\begin{abstract}
This study aims to improve reading skills beginning with word card media for the first grade students of UPT. SD Negeri 04 Baringin, Lima Kaum District, Tanah Datar Regency. This research is a Classroom Action Research (CAR) which is descriptive qualitative using qualitative teaching reinforced by a quantitative approach, by taking the UPT background. SD Negeri 04 Baringin. The subjects of this study were students of class I at UPT. SD Negeri 04 Baringin, while the object of this research is the improvement of reading skills beginning with word card media on the theme of a clean, healthy and beautiful environment. This research was conducted in three cycles and through four stages including: (1) planning, (2) implementation, (3) observation, and (4) reflection. Data obtained through observation, interviews, reading tests and documentation. Data analysis was performed using qualitative analysis consisting of data reduction, data presentation, drawing conclusions or verification. The results showed that the word card media could improve students' beginning reading skills. The increase in student learning activities can be measured from the evaluation of cycle I and II with the value of student learning activities in the first cycle of $67.50 \%$ and the second cycle of $83.13 \%$. Meanwhile, the results of the test for the improvement of reading skills at the beginning can be measured from each cycle, the reading skills of students in the first cycle were 71.01 (not yet reaching the KKM), the reading skills in the second cycle were 82.70 (had reached the KKM). Thus the results of the research of class 1 UPT students SD Negeri 04 Baringin
\end{abstract}

Keywords: Reading the beginning, word card media.

Abstrak: Penelitian ini bertujuan untuk meningkatkan keterampilan membaca permulaan dengan media kartu kata pada siswa kelas 1 UPT. SD Negeri 04 Baringin, Kecamatan Lima Kaum, Kabupaten Tanah Datar. Penelitian ini merupakan Penelitian Tindakan Kelas (PTK) yang bersifat deskriptif kualitatif dengan menggunakan pendekan kualitatif yang diperkuat dengan pendekatan kuantitatif, dengan mengambil latar UPT. SD Negeri 04 Baringin. Subjek penelitian ini adalah siswa kelas I di UPT. SD Negeri 04 Baringin, sedangkan objek penelitian ini adalah peningkatan keterampilan membaca permulaan dengan media kartu kata pada tema lingkungan bersih, sehat dan asri. Penelitian ini dilakukan dalam tiga siklus dan melalui empat tahapan yang mencakup: (1) perencanaan, (2) pelaksanaan, (3) observasi, dan (4) refleksi. Data diperoleh melalui observasi, wawancara, tes membaca dan dokumentasi. Analisis data dilakukan dengan menggunakan analisis kualitatif yang terdiri dari reduksi data, penyajian data, penarikan kesimpulan atau verifikasi. Hasil penelitian menunjukkan bahwa media kartu kata dapat meningkatkan keterampilan membaca permulaan siswa. Peningkatan aktifitas belajar siswa dapat diukur dari evaluasi siklus I, dan II dengan nilai aktifitas belajar siswa pada siklus I sebesar $67,50 \%$ dan siklus II sebesar 83,13\%. Sedangkan hasil tes peningkatan keterampilan membaca permulaan dapat diukur dari setiap siklusnya, 
keterampilan membaca siswa pada siklus I sebesar 71,01 (belum mencapai KKM), keterampilan membaca pada siklus II sebesar 82,70 (sudah mencapai KKM).

Kata Kunci: Membaca permulaan, media kartu kata.

\section{A. Pendahuluan}

Pendidikan merupakan usaha sadar dan terencana untuk mewujudkan suasana belajar dan proses pembelajaran agar peserta didik secara aktif mengembangkan potensi dirinya untuk memiliki kekuatan spiritual keagamaan, pengendalian diri, kepribadian, kecerdasan, akhlak mulia, serta keterampilan yang diperlukan dirinya, masyarakat, bangsa dan negara (UU RI No.20 Tahun 2003 tentang sistem nasional). Berdasarkan undang-undang No 20 Tahun 2003 tentang sistem pendidikan nasional menyebut, bahwa pendidikan nasional berfungsi mengembangkan kemampuan dan membentuk watak serta peradaban bangsa yang bermartabat dalam rangka mencerdaskan kehidupan bangsa. Pendidikan bertujuan untuk mengembangkan potensi peserta didik agar menjadi manusia yang baik dan beriman bertakwa kepada Tuhan Yang Maha Esa, berakhlak mulia, sehat Jasmani maupun Rohani, berilmu, cakap, kreatif dan terampil, mandiri dan menjadi warga yang demokratis serta bertanggung jawab (Trianto, 2010: 1).

Standar Isi Satuan Pendidikan Dasar dan Menengah untuk Kelas 1 SD (Depdiknas, 2006: 149) menjelaskan bahwa berbahasa dan bersastra meliputi empat aspek, yaitu: aspek mendengarkan, aspek berbicara, aspek membaca, dan aspek menulis. Keempat aspek kemampuan berbahasa dan bersastra tersebut memang berkaitan erat sehingga merupakan satu kesatuan yang tidak dapat dipisahkan. Kegiatan membaca merupakan salah satu jenis kemampuan berbahasa tulis yang bersifat reseptif. Disebut reseptif karena dengan membaca seorang akan memperoleh informasi, memperoleh ilmu dan pengetahuan serta pengalaman-pengalaman baru. Semua yang diperoleh melalui bacaan akan memungkinkan seseorang mempertinggi daya pikirnya, mempertajam pandangannya, dan memperluas wawasannya (Darmiyati Zuchdi dan Budiasih, 2001: 16).

Berdasarkan pada Standar Isi Satuan Pendidikan Dasar dan Menengah untuk kelas satu pada mata pelajaran Bahasa Indonesia di Sekolah Dasar (Depdiknas, 2006: 148) bertujuan agar peserta didik mempunyai kemampuan sebagai berikut: a) berkomunikasi secara efektif dan efisien dengan etika yang berlaku baik lisan maupun tulisan, b) Menghargai dan bangga menggunakan Bahasa Indonesia sebagi Bahasa Persatuan dan Bahasa Negara, c) Memahami Bahasa Indonesia dan menggunakan dengan tepat dan kreatif untuk berbagai tujuan, d) Menggunakan Bahasa Indonesia untuk meningkatkan intelektual serta kematangan emosional dan sosial, e) Menikmati dan memanfaatkan karya sastra untuk memperluas wawasan, memperluas budi pekerti, meningkatkan pengetahuan dan keterampilan berbahasa, f) Menghargai dan membanggakan sastra Indonesia sebagai khasanah budaya dan intelektual manusia Indonesia. Kegiatan membaca merupakan aktivitas yang unik dan rumit, sehingga seseorang tidak dapat melakukan hal tersebut tanpa mempelajarinya terutama anak usia Sekolah Dasar yang baru mengenal huruf atau kata-kata. Problem umum yang dihadapi anak dalam membaca adalah pada pelaksanaan pengajaran membaca, guru sering kali dihadapkan anak yang mengalami kesulitan, baik yang berkenaan dengan hubungan huruf, suku kata, kalimat sederhana, maupun ketidakmampuan anak memahami isi bacaan.

Berdasarkan dari hasil observasi peneliti di UPT. SD Negeri 04 Baringin Kecamatan Lima Kaum, diperoleh data banyak siswa yang memiliki permasalahan EISSN 2657-0289 Lembaga Penelitian dan Penerbitan Hasil Penelitian Ensiklopedia 
terutama dalam hal membaca khususnya di kelas rendah yaitu kelas 1 (satu). Banyak data siswa keseluruhan 35 siswa, ada 20 siswa yang masih belum bisa membaca dan 15 siswa lainnya sudah bisa membaca walaupun belum begitu lancar. Hal inilah yang dijadikan peneliti sebagai alasan mengapa peneliti mengangkat permasalahan ini. Pembelajaran membaca permulaan di UPT. SD Negeri 04 Baringin Kecamatan Lima Kaum selama ini masih belum mengoptimalkan media pembelajaran yang ada di sekolah. Proses pembelajaran menggunakan media konvensional yaitu dengan papan tulis dan pembelajaran hanya berpusat kepada guru. Hal ini menyebabkan kemampuan membaca permulaan siswa masih sangat rendah. Media Kartu Kata yang ada di sekolah tidak dipergunakan sebagaimana mestinya dan hanya disimpan di dalam lemari.

Untuk meningkatkan prestasi belajar membaca siswa di kelas 1 SD maupun Madrasah Ibtidaiyah, guru diharapkan mempunyai kemampuan dan keterampilan dalam memilih serta menggunakan pendekatan pembelajaran secara tepat. Pendekatan pembelajaran Bahasa lebih ditekankan pada pendekatan komunikatif, yaitu keterampilan menggunakan Bahasa Indonesia yang baik dan benar untuk berkomunikasi. Pendekatan komunikatif sepenuhnya dapat diterapkan dalam proses belajar mengajar di kelas apabila siswa terlibat aktif. Siswa tidak saja dilibatkan sejak awal dalam tahap memilih tema dan menentukan topik sajian bahan pengajaran. Dengan demikian siswa dapat merasakan bahwa kegiatan belajar yang dilakukan menjadi milik dan tanggung jawabnya. Tingkat keaktifan siswa yang paling tinggi adalah kemandirian siswa dalam belajar, keingintahuan yang tinggi, kehausan mencari informasi baru, dan kelincahan dalam mencari pemecahan masalah.

Penggunaan model pembelajaran dan media sangat membantu dalam pengajaran membaca permulaan bagi siswa kelas 1 SD merupakan hal yang mutlak diperlukan, anak kelas 1 SD yang pada umumnya baru berusia 6 (enam) tahun masih berada pada taraf berfikir konkret, yaitu anak akan mudah mengenali hal-hal yang bersifat nyata. Di samping itu, dengan alat bantu yang digunakan oleh guru secara bervariasi akan membangkitkan minat siswa dalam mengikuti pelajaran. Salah satu media yang memungkinkan digunakan oleh guru dalam pengajaran membaca permulaan ini adalah melalui media kartu huruf. Berdasarkan uraian di atas, maka perlu dilakukan sebuah penelitian tentang penggunaan media dan metode yang tepat untuk meningkatkan kemampuan membaca siswa khususnya di UPT. SD Negeri 04 Baringin. Oleh karena itu,penulis mengangkat judul penelitian " Peningkatan Keterampilan Membaca Permulaan Dengan Media Kartu Kata Tema Lingkungan Bersih, Sehat, dan Asri Pada Siswa Kelas 1 UPT. SD Negeri 04 Baringin”.

Berdasarkan latar belakang masalah tersebut di atas maka peneliti mengidentifikasi masalah dalam penelitian ini sebagai berikut: 1) Keterampilan membaca siswa dengan penggunaan lafal dan intonasi yang belum tepat; 2) Siswa masih membaca dengan suara yang belum jelas dan belum tepat dalam pengucapannya; 3) Siswa masih kesulitan memahami dari kata dan kalimat yang dibacanya; 4) Pembelajaran membaca permulaan yang dilakukan hanya terbatas dengan penggunaan buku dan papan tulis; 5) Motivasi dan minat siswa kurang dalam mengikuti pembelajaran; dan 6) Nilai rata-rata keterampilan membaca siswa kelas 1(satu) masih tergolong rendah. Agar penelitian ini lebih terarah dan sesuai dengan tujuan yang diharapkan, perlu adanya batasan masalah dalam penelitian sebagai berikut: 1) Penelitian dilaksanakan pada kelas I UPT. SD Negeri 04 Baringin; dan 2) 
Penelitian berfokus pada keterampilan membaca permulaan siswa kelas I (satu) dengan menggunakan media kartu kata.

\section{B. Metodologi Penelitian}

Desain atau rancangan dalam penelitian ini adalah Penelitian Tindakan Kelas (PTK). PTK adalah suatu pencermatan terhadap kegiatan belajar berupa sebuah tindakan, yang sengaja dimunculkan dan terjadi dalam sebuah kelas secara bersama (Arikunto, 2012: 1). Prosedur Penelitian Tindakan Kelas (PTK) dimulai dengan siklus pertama yang terdiri dari empat kegiatan, yaitu: perencanaan (planning), tindakan (acting), pengamatan (observing), refleksi (reflecting). Penelitian Tindakan Kelas (PTK) ini dilaksanakan melalui 3(Tiga) siklus untuk melihat hasil peningkatan Keterampilan Membaca Pemulaan Siswa Kelas 1 (satu) dengan menggunakan Media Kartu Kata. Masing-masing siklus dengan tahap: perencanaan, pelaksanaan, pengamatan, refleksi dengan kolaborasi antara peneliti dengan guru kelas I di UPT. SD Negeri 04 Baringin Kecamatan Lima Kaum Kabupaten Tanah Datar, berikut ini adalah tahap perencanaan, pelaksanaan, pengamatan, dan refleksi yang dilakukan pada setiap siklus. Apabila peneliti sudah mengetahui letak keberhasilan dan hambatan dari tindakan pada siklus I, maka peneliti dan guru berkolaborasi menentukan rancangan tindakan berikut pada siklus II, maka peneliti dan guru berkolaborasi melanjutkan kegiatan Penelitian Tindakan Kelas (PTK) seperti pada siklus I. jika telah selesai pelaksanaan pada siklus II, apabila peneliti belum merasa puas untuk perbaikan dan peningkatan atas tindakan tersebut, peneliti dapat melanjutkan penelitian kedalam siklus III, yang cara pelaksanaannya sama siklus sebelumnya. Tidak ada ketentuan atau ketetapan beberapa siklus yang harus dilakukan oleh peneliti dalam melakukan Penelitian Tindakan Kelas (PTK). Hal ini tergantung dengan peneliti, jika hasil penelitian telah menemukan hasil yang memuaskan dalam perbaikan dan peningkatan proses pembelajaran di kelas maka peneliti dapat menghentikan dan mengambil kesimpulan, namun disarankan sebaiknya PTK dilakukan paling kurang dua siklus (Iskandar, 2012: 48). Tahapan setelah pengumpulan data adalah analisis data. Dalam penelitian ini analisis dilakukan peneliti dari awal pada setiap aspek kegiatan penelitian. Metode pembelajaran yang digunakan dalam proses belajar mengajar juga membutuhkan data yakni hasil, adakah peningkatan minat masing-masing siswa untuk aktiif dalam proses pembelajaran oleh peneliti, pada data kualitatif yang dikembangkan oleh Miles dan Huberman yang terdiri dari beberapa komponen yaitu: 1) Reduksi data merupakan proses menyeleksi, menentukan, fokus, menyederhanakan, meringkas dan mengubah bentuk data mentah yang ada dalam catatan lapangan. Dalam proses ini dilakukan penajaman, pemilihan, pemfokusan, penyelisihan data yang kurang bermakna dan menatanya sedemikian rupa, sehingga kesimpulan akhir dapat ditarik dan diverifikasikan; 2) Penyajian data setelah direduksi, data siap diberikan. Artinya analisis sampai pada pembeberan dara, berbagai macam data perlu diteliti tindakan yang telah direduksikan perlu dibeberkan dengan tertata rapidalam bentuk narasi,matrik grafik atau diagram; dan 3) Penarikan kesimpulan, peningkatan atau perubahan yang terjadi dilakukan secara bertahap mulai dari kesimpulan sementara yang ditarik pada akhir siklus I dan terevisi pada siklus II (Sugiyono, 2013: 338). 


\section{Hasil dan Pembahasan Deskripsi Kondisi Awal}

Berdasarkan hasil observasi di kelas I UPT. SD Negeri 04 Baringin diketahui terdapat beberapa siswa yang belum bisa membaca, hal tersebut membuat guru sulit untuk menyampaikan materi dengan baik. Hal tersebut dikarenakan kurangnya media pembelajaran yang guru gunakan dan kurangnya bimbingan orang tua terhadap anaknya yang belum bisa membaca. Pembelajaran dalam aspek membaca siswa hanya berpedoman pada buku dan mengikuti bacaan yang diucapkan oleh guru.

Berikut data awal keterampilan membaca siswa pada pembelajaran Tematik yang berfokus pada mata pelajaran Bahasa Indonesia yang dilakukan peneliti pada saat observasi berlangsung.

Tabel Deskripsi Keadaan Hasil Belajar Siswa Sebelum Penelitian/Pra Siklus

\begin{tabular}{|c|c|c|c|c|}
\hline No & Nama Siswa & Nilai & Tuntar & $\begin{array}{l}\text { Belum } \\
\text { Tuntas }\end{array}$ \\
\hline 1 & Adbyastha Zayyan Danendra & 40 & & $\sqrt{ }$ \\
\hline 2 & Aisyah Arnita & 75 & $\sqrt{ }$ & \\
\hline 3 & Altaf Kiandra Ramadhan & 75 & $\sqrt{ }$ & \\
\hline 4 & Alya Shakila & 55 & & $\sqrt{ }$ \\
\hline 5 & Alya Zahra & 75 & $\sqrt{ }$ & \\
\hline 6 & Assyifa Varen & 50 & & $\sqrt{ }$ \\
\hline 7 & Audrey Kharza Arya & 30 & & $\sqrt{ }$ \\
\hline 8 & Aura Princees Ramiro & 75 & $\sqrt{ }$ & \\
\hline 9 & Azzbura Prayasa Nasution & 70 & & $\sqrt{ }$ \\
\hline 10 & Daanivah Salsabila Syaugi & 75 & $\sqrt{ }$ & \\
\hline 11 & Dzakira Talita Zahra & 70 & & $\sqrt{ }$ \\
\hline 12 & Feodora Callysta & 75 & $\sqrt{ }$ & \\
\hline 13 & Ferlin Dreef Viona & 75 & $\sqrt{ }$ & \\
\hline 14 & Hana Damia Yanil & 65 & & $\sqrt{ }$ \\
\hline 15 & Harfa Zidnnafan & 60 & & $\sqrt{ }$ \\
\hline 16 & Jihan Rahayu Putri & 70 & & $\sqrt{ }$ \\
\hline 17 & Kaisab Ahla Tanimah & 75 & $\sqrt{ }$ & \\
\hline 18 & Luthfi Dbafa Fernanda & 40 & & $\sqrt{ }$ \\
\hline 19 & Muhammad Asra Ozella & 60 & & $\sqrt{ }$ \\
\hline 20 & Muhammad Dwi Rhafa & 75 & $\sqrt{ }$ & \\
\hline 21 & Muhammad Fatih Alghifari & 55 & & $\sqrt{ }$ \\
\hline 22 & Muhammad Haikal Agusda & 75 & $\sqrt{ }$ & \\
\hline 23 & Muhammad Rahma Alhakim & 50 & & $\sqrt{ }$ \\
\hline 24 & Nawaitul Jhannah & 60 & & $\sqrt{ }$ \\
\hline 25 & Nayra Syabilla Azzahra & 75 & $\sqrt{ }$ & \\
\hline 26 & Qiannah Hafiza Qisthi & 45 & & $\sqrt{ }$ \\
\hline 27 & Qiesba Syakixa & 75 & $\sqrt{ }$ & \\
\hline 28 & Rheyando Ananditho & 75 & $\sqrt{ }$ & \\
\hline 29 & Ruffi Mirza & 50 & & $\sqrt{ }$ \\
\hline 30 & Sachio Claresta & 75 & $\sqrt{ }$ & \\
\hline 31 & Samudra Wibawa & 40 & & $\sqrt{ }$ \\
\hline 32 & Syaisa Humairah & 50 & & $\sqrt{ }$ \\
\hline 33 & Tsagif Aziz Rafares & 70 & & $\sqrt{ }$ \\
\hline 34 & Wildan Rasyid & 75 & $\sqrt{ }$ & \\
\hline 35 & Zahida Qalbi Nadhifa & 70 & & $\sqrt{ }$ \\
\hline \multicolumn{2}{|c|}{ Jumlab } & 2235 & 15 & 20 \\
\hline Skor & Rata-Rata & 63.86 & & \\
\hline \multicolumn{3}{|c|}{ Persentase, Ketuntasan Siswa } & $42,86 \%$ & $57,14 \%$ \\
\hline
\end{tabular}

Berdasarkan data tersebut, dapat diperoleh bahwa skor rata-rata keterampilan membaca permulaan siswa adalah 63,86 (Rendah). Sedangkan yang dapat memenuhi Kriteria Ketuntasan Minimum (KKM) hanya 15 siswa dari 35 siswa yang ada di kelas I, hal ini menandakan bahwa keterampilan membaca siswa masih rendah. Berdasarkan temuan pada data prasiklus dapat disimpulkan bahwa rata-rata keterampilan membaca siswa kelas I di UPT. SD Negeri 04 Baringin termasuk ke dalam kategori "Rendah".Hal tesebut dikarenakan rendahnya kualitas keterampilan membaca siswa. Guru belum menerapkan media pembelajaran yang inovatif pada aspek membaca, guru

50 Lembaga Penelitian dan Penerbitan Hasil Penelitian Ensiklopedia $\quad$ EISSN 2657-0289 PISSN 2657-0297 
belum menggunakan media yang tepat, sehingga siswa masih banyak yang belum bisa membaca. Pada pembelajaran tematik mata pelajaran Bahasa Indonesia khususnya pada aspek membaca, siswa masih sangat rendah. Berdasarkan permasalahan di atas, maka dari itu guru harus dapat menerapkan media pembelajaran yang tepat dan sesuai dengan materi yang akan diajarkan kepada siswa, yang dapat menarik perhatian siswa sehingga pembelajaran khususnya aspek keterampilan membaca dapat meningkat.

\section{Deskripsi Hasil Siklus I}

Pelaksanaan siklus pertama dilakukan selama 2 kali pertemuan dengan memberikan tes membaca secara langsung siklus 1 kepada siswa dengan penilaian lafal, intonasi, kelancaran kenyaringan kejelasan suara. Kegiatan yang dilaksanakan pada siklus I yaitu meliputi perencanaan, pelaksanaan, observasi dan refleksi. Berdasarkan hasil pengamatan di atas, sebagaimana ditunjukkan pada tabel dapat diketahui bahwa aktifitas guru pada proses pembelajaran Bahasa Indonesia dalam keterampilan membaca menggunakan media kartu kata siklus 1 sudah cukup baik, hal ini dapat dilihat dari persentase setiap hasil itemnya. Tetapi masih ada terlihat beberapa kekurangan yaitu pada saat guru menjelaskan di depan siswa masih ada yang kurang fokus memperhatikan guru, guru juga belum sepenuhnya menegur siswa yang ramai ketika guru memberikan penjelasan. Hal ini menyebabkan suasana kelas menjadi tidak kondusif. 
Tabel

Hasil Belajar Siswa Menggunakan Media Kartu Kata dalam keteramiran membaca (siklus I)

\begin{tabular}{|c|c|c|c|c|c|}
\hline \multirow[t]{2}{*}{ No } & \multirow[t]{2}{*}{ Nma Siswa } & \multicolumn{2}{|c|}{$\begin{array}{c}\text { Nilai Tes Evaluasi } \\
\text { Siklus I }\end{array}$} & \multirow{2}{*}{$\begin{array}{c}\text { Rata- } \\
\text { rata }\end{array}$} & \multirow{2}{*}{$\begin{array}{c}\text { Keteranga } \\
\mathbf{n}\end{array}$} \\
\hline & & \multicolumn{2}{|c|}{$P 1$} & & \\
\hline 1 & $\begin{array}{l}\text { Adbyastha Zayyau } \\
\text { Danendra. }\end{array}$ & 55 & 68 & 615 & idak Tuntas \\
\hline 2 & Aisyah Arnita & 75 & 80 & 77.5 & Tuntas \\
\hline 3 & Altaf Kiandra Ramadhan & 75 & 80 & 775 & Tuntas \\
\hline 4 & Alya Shakila & 66 & 75 & 70.5 & idak Tuntas \\
\hline 5 & Alya Zahra & 75 & 75 & 75 & Tuntas \\
\hline 6 & Assyifit Varen & 50 & 66 & 58 & idak Tuntas \\
\hline 7 & Audrey Khanza Arya & 50 & 61 & 55.5 & idak Tuntas \\
\hline 8 & Aura Princees Ramiro & 75 & 75 & 75 & Tuntas \\
\hline 9 & Azchura Prayasa Nasution & 75 & 80 & 77.5 & Tuntas \\
\hline 10 & Daaniyah Salsabjila Syaugi & 75 & 75 & 75 & Tuntas \\
\hline 11 & Dzakira Talita Zahra & 78 & 80 & 79 & Tuntas \\
\hline 12 & Feodora Callysta. & 75 & 75 & 75 & Tuntas \\
\hline 13 & Ferlin Dreef Viona & 75 & 80 & 775 & Tuntas \\
\hline 14 & Hana Damia Yanil & 68 & 75 & 71.5 & idak Tunfas \\
\hline 15 & Harfa Zidnnafan & 66 & 75 & 70.5 & idak Tuntas \\
\hline 16 & Jihan Rahayu Putri & 75 & 80 & 77.5 & Tuntas \\
\hline 17 & Kaisah Ahla Tanimah & 75 & 75 & 75 & Tuntas \\
\hline 18 & Luthfi Dhafa Fernanda & 51 & 63 & 57 & Lidak Tuntas \\
\hline 19 & Muhammad Asra Ozella & 61 & 73 & 67 & Lidak Tuntas \\
\hline 20 & Muhammad Dwi Rhafa & 75 & 80 & 775 & Tuntas \\
\hline 21 & $\begin{array}{l}\text { Muhammad Fatih } \\
\text { Alghifari }\end{array}$ & 60 & 73 & 66.5 & idak Tuntas \\
\hline 22 & $\begin{array}{l}\text { Muhammad Haikal } \\
\text { Agusda }\end{array}$ & 75 & 80 & 77.5 & Tuntas \\
\hline 23 & $\begin{array}{l}\text { Muhammad Rahma } \\
\text { Albakim. }\end{array}$ & 56 & 68 & 62 & idak Tuntas \\
\hline 24 & Nawaitul Jhannah & 66 & 75 & 70.5 & idak Tuntas \\
\hline 25 & Nayra Syabilla Azzahra & 75 & 75 & 75 & Tuntas \\
\hline 26 & Qiannah Hafiza Qisthi & 50 & 61 & 55.5 & idak Tuntas \\
\hline 27 & Qiesha Syakira & 78 & 78 & 78 & Tuntas \\
\hline 28 & Rheyando Ananditho. & 75 & 80 & 775 & Tuntas \\
\hline 29 & Rufti Mirza & 61 & 73 & 67 & idak Tuntas \\
\hline 30 & Sachio Claresta & 75 & 80 & 77.5 & Tuntas \\
\hline 31 & Samudra Wibawa & 78 & 80 & 79 & Ridak Tuntas \\
\hline 32 & Syaisa Humairah & 50 & 61 & 55.5 & fidak Tuntas \\
\hline 33 & Tsagif Aziz Rafares & 51 & 63 & 57 & Tuntas \\
\hline 34 & Wildan Rasyid & 78 & 80 & 79 & Tuntas \\
\hline 35 & Zabida Qalbi Nadhifa & 75 & 80 & 77.5 & Tuntas \\
\hline & Jumlah & 2373 & 2598 & 2485.5 & \multirow{3}{*}{$\begin{array}{c}\text { Belum } \\
\text { Mencapai. } \\
\text { KKM }\end{array}$} \\
\hline & Rata-rata & 67.8 & 74.23 & 7101 & \\
\hline & Siswa yang tunfas & 20 & 24 & 20 & \\
\hline
\end{tabular}

Adapun hasil tes evaluasi pada siklus 1 pada aspek keterampilan membaca menggunakan media kartu kataterdapat pada tabel nilai siswa dengan rata-rata 71,01 belum mencapai Kriteria Ketuntasan Minimum (KKM). Dimana hasil keterampilan membaca siswa belum meningkat, siswa yang semula belum tuntas pada siklus 1 ini sudah mendapatkan nilai yang cukup bagus, siswa yang sudah tuntas pada pra siklus lebih meningkat lagi nilainya, masih ada 15 orang siswa $(42,86 \%)$ yang belum tuntas sedangkan 20 orang siswa atau $57,14 \%$ yang sudah tuntas pada saat tes evaluasi siklus I. Hasil yang diperoleh sebagian besar siswa menunjukkan ketuntasan yang lebih baik dibandingkan dengan ketuntasan pada saat pra siklus melalui media kartu kata dalam keterampilan membaca siswa sudah terlihat cukup antusias dalam pembelajaran dan ikut berpartisipasi sehingga pada saat tes evaluasi siswa bisa membaca dengan lafal dan intonasi yang sudah cukup baik.

\section{Deskripsi Hasil Siklus II}

Pelaksanaan siklus kedua dilakukan selama 2 kali pertemuan pembelajaran dengan memberikan tes membaca secara langsung siklus II kepada siswa dengan 
penilaian lafal, intonasi, kelancaran kenyaringan kejelasan suara. Kegiatan yang dilaksanakan pada siklus I yaitu meliputi perencanaan, pelaksanaan, observasi dan refleksi. Berdasarkan hasil pengamatan di atas, sebagaimana ditunjukkan pada table dapat diketahui bahwa aktifitas guru pada proses pembelajaran Bahasa Indonesia dalam keterampilan membaca menggunakan media kartu kata siklus II sudah aktif, hal ini dapat dilihat dari persentase setiap hasil itemnya. Guru sudah menggunakan media kartu kata yang membuat keberhasilan yaitu pada aspek keterampilan membaca pada siswa. Pada saat menjelaskan materi cukup jelas karena bagian-bagian yang belum dipahami siswa diulang dan diulas kembali oleh guru. Guru telah memberikan kesempatan bagi siswa untuk menanyakan hal-hal yang belum dipahami siswa, guru membimbing siswa dalam kelompok ataupun individu yang mengalami kesulitan dalam membaca.

Tabel Hasil Belajar Siswa Menggunakan Media Kartu Kata dalam keteramiran membaca (siklus II)

\begin{tabular}{|c|c|c|c|c|c|}
\hline Sis & Dima Siswa & $\begin{array}{l}\text { Nilasi Tee } \\
\text { Evaluasi } \\
\text { Sikilus } 1 \\
\end{array}$ & $\begin{array}{c}\text { Rata- } \\
\text { ratai }\end{array}$ & Keterangan & \\
\hline 1 & 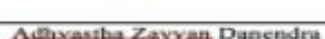 & $\frac{\mathrm{PI}}{78}$ & $P 2$ & 815 & 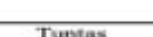 \\
\hline$\frac{1}{2}$ & Aisyah Armita & $\frac{78}{85}$ & $\frac{H 5}{90}$ & $\frac{81.5}{87.5}$ & Tentas \\
\hline 3 & Altaf Ki indira Ramodhan & 85 & 90 & 87.5 & Tumtas \\
\hline 4 & Alya shakila & 80 & R5 & 82.5 & Tumfas \\
\hline 5 & Alya Zahra & 80 & K5 & 82.5 & Tumtas \\
\hline$\frac{3}{6}$ & Assyifa Waren & 78 & BS & 81.5 & Tuntas \\
\hline 7 & Alidrey Khastra Arya & 61 & 73 & 67 & Tidak Tuntas \\
\hline 8 & Avira Brincsess Ramina & 80 & 85 & 82.5 & Tuntas \\
\hline 9 & Axflturn. Fxayasa Nasution & 90 & 95 & 92.5 & Tumtas \\
\hline 10 & Daanixah Sulanbila Svavai & 80 & K5 & 8.25 & Tumbias \\
\hline 11 & Drakira Talita Zahra & 85 & 95 & 90 & Tuntas \\
\hline 12 & Ecodared Callosiat & 80 & 80 & so & Tumtas \\
\hline 13 & Ferilin Drost Vioma & 90 & 90 & 90 & Tuntas \\
\hline 14 & Itana Damia Yaath & 80 & 80 & 80 & Tuntias \\
\hline 15 & Ilarcin Zadnenalan & 75 & 75 & 75 & Tumba: \\
\hline 16 & Jihan Rahayu Putri & 80 & 80 & 80 & Tuntas \\
\hline 17 & Kaisabs Abla Tynimah & 75 & 75 & 75 & Tuntus \\
\hline 18 & Luthfi Dhaffa. Fermanda & 71 & 71 & 71 & Tidak Tumtas \\
\hline 19 & Muhammad Asra Ozella & 78 & B8 & 83 & Tuntas \\
\hline 20 & Mulhamamais Dowi Elatifa & 80 & 90 & 85 & Tuntas \\
\hline 21 & Mahammad Fatih Alvhifari & 75 & 85 & 80 & Tumtas \\
\hline 22 & Muhammad Haikal Arueda & 80 & 90 & 85 & Tuntass \\
\hline 23 & Muhametranal Mahma Alhakim & 78 & H. & 83 & Tumbas \\
\hline 24 & Nawaitul Jhannah & 80 & \$55 & 82.5 & Tuntas \\
\hline$\frac{24}{25}$ & Naxza Syabilla Areahra & 80 & 90 & $\frac{8.3}{85}$ & Tumtas \\
\hline 26 & Oianaah. Hafixa Oisthi & 73 & No & 76.5 & Tuntias \\
\hline 27 & Oieshe Svakira & 83 & 88 & 85.5 & Tuntass \\
\hline$\frac{27}{28}$ & RhexandaAneaclithe. & 85 & 90 & $\frac{83.3}{87.5}$ & $\begin{array}{l}\text { Munins } \\
\text { Tuntas }\end{array}$ \\
\hline 29 & Ruffi Mirra & 83 & 85 & 84 & Tumtas \\
\hline 30 & Sacthin Claresta & 85 & 90 & 87.5 & Tuntas \\
\hline 31 & Samudra Wiluewa & 85 & 95 & 90 & Tuntas \\
\hline 32 & Svaisal Humairah & 6.8 & 70 & 69 & Tidak Tentas \\
\hline 33 & Tsagir Ariz Reforct & 75 & 85 & 80 & Tumtas \\
\hline$\frac{33}{34}$ & Wildan Ratrid & $\frac{13}{85}$ & 95 & $\frac{80}{90}$ & Tumbias \\
\hline 35 & Zahida Oalbi Nadhifa & 90 & 95 & 92.5 & Tuntas \\
\hline Jumlah & 2796 & 2993 & 2894.5 & \multirow{5}{*}{$\begin{array}{l}\text { Kudah } \\
\text { Mencapai } \\
\text { KKMM } \\
\text { Indikator } \\
\text { Keberhasilan }\end{array}$} & Fumias \\
\hline Rata-rata & $79 . \mathrm{k9}$ & 85.51 & 82.70 & & \\
\hline Siswa yang & 31 & 32 & 32 & & \\
\hline $\begin{array}{l}\text { Siswa yang } \\
\text { tidak tumtas }\end{array}$ & 4 & 3 & 3 & & \\
\hline $\begin{array}{l}\text { Becsestasisiswas } \\
\text { tuntas }\end{array}$ & $8 \times, 5756$ & 91,4356 & $91.43 \%$ & & \\
\hline $\begin{array}{l}\text { Recaentaraj siawa } \\
\text { tidak tuntas }\end{array}$ & $11,43 \%$ & $8,57 \%$ & 8,5796 & & \\
\hline
\end{tabular}

Adapun hasil tes evaluasi pada siklus II pada aspek keterampilan membaca menggunakan media kartu kata terdapat pada table 4.9 nilai siswa dengan rata-rata 82,70 sudah mencapai Kriteria Ketuntasan Minimum (KKM), walaupun belum seluruh siswa kelas I tuntas dalam keterampilan membaca, masih ada 3 siswa yang belum tuntas dalam mengikuti tes evaluasi. Tetapi hasil tes evaluasi pada siklus II sudah ada peningkatan dibandingkan hasil tes evaluasi pada siklus I, hasil tes evaluasi yang dilakukan siswa sangat meningkat dari siklus I yang sebelumnya hanya mencapai ratarata $57,14 \%$.

\section{Pembahasan Hasil Penelitian}

Penelitian ini merupakan penelitian tindakan kelas yang bertujuan untuk meningkatkan keterampilan membaca siswa kelas I di di UPT. SD Negeri 04 Baringin Kecamatan Lima Kaum Kabupaten Tanah Datar. Pelaksanaan penelitian pada 
keterampilan membaca pada siswa UPT. SD Negeri 04 Baringin yang masih rendah dilakukan dengan tindakan pembelajaran dengan menggunakan media kartu kata dengan ejaan yang belum dikuasai siswa yaitu huruf vokal, konsonan, gabungan konsonan dan huruf diftong yang dituliskan pada sebuah kartu kata dengan ukuran 18 x $6 \mathrm{~cm}$ dan 13 x $6 \mathrm{~cm}$ pada tulisan tersebut menggunakan variasi warna dan pemenggalan suku kata yang dibedakan dengan warna.

Pembelajaran membaca dengan menggunakan media kartu kata yang dilaksanakan didasari dari: 1) Pembelajaran membaca harus memperhatikan faktor psikologis yaitu yang dapat membangkitkan semangat dan minat siswa; 2) Penggunaan kartu kata dengan variasi warna didasarkan pada prinsip-prinsip penggunaan media visual diantaranya prinsip kesederhanaan, dengan media yang sederhana maka mudah dibuat oleh guru dan dapat dengan mudah dioperasikan oleh siswa kelas rendah, prinsip penekanan yaitu dengan menggunakan ukuran yang dapat terlihat jelas, prinsip warna agar dapat menarik motivasi siswa; 3) Hasil observasi aktivitas belajar siswa pada siklus I diperoleh rata-rata persentase sebesar $67,50 \%$, sedangkan pada siklus II diperoleh rata-rata persentase sebesar $83,13 \%$. Hal ini menunjukkan adanya peningkatan aktivitas belajar siswa dalam proses pembelajaran Bahasa Indonesia aspek keterampilan membaca dengan media kartu kata; 4) Hasil aktivitas mengajar guru pada siklus I diperoleh rata-rata persentase sebesar $71,25 \%$, sedangkan pada siklus II diperoleh rata-rata persentase sebesar $87,50 \%$. Hal ini pun menunjukkan adanya peningkatan kemampuan guru dalam mengelola kelas dan menggunakan media kartu kata sehingga mampu meningkatkan keterampilan membaca siswa; dan 5) Hasil observasi keterampilan membaca siswa pada siklus I diperoleh rata-rata persentase sebesar 57,14\% sedangkan pada siklus II diperoleh rata-rata persentase sebesar 88,57\% Hal ini pun menunjukkan adanya peningkatan keterampilan membaca siswa dengan media kartu kata.

Berdasarkan hasil analisis data yang dilakukan maka diperoleh informasi bahwa pada pelaksanaan siklus I dari hasil observasi yang dilakukan selama proses pembelajaran menunjukan aktivitas belajar dan hasil belajar siswa belum begitu optimal. Namun terjadi peningkatan pada aktivitas belajar dan hasil belajar siswa setelah dilakukan perbaikan-perbaikan pada siklus II dengan hasil sangat baik. Adapun data yang diperoleh adalah sebagai berikut: Lembar observasi digunakan sebagai pedoman bagi observer dalam melakukan pengamatan terhadap keaktifan belajar siswa dan aktivitas mengajar guru selama proses pembelajaran berlangsung. Hasil yang diperoleh dari lembar observasi digunakan peneliti dan observer sebagai bahan untuk melakukan refleksi terhadap pelaksanaan tindakan yang telah dilakukan dan sebagai acuan untuk melakukan perbaikan pada siklus selanjutnya. Hasil observasi yang diperoleh pada penelitian ini adalah sebagai berikut:

Tabel Persentase Aktivitas Belajar Siswa Dengan Menggunakan Media Kartu

Kata

\begin{tabular}{|c|c|c|c|}
\hline Skor & Pertemuan 1 & Pertemuan 2 & Rata - rata \\
\hline Siklus I & $61,25 \%$ & $73,75 \%$ & $67,50 \%$ \\
\hline Siklus II & $77,50 \%$ & $88,75 \%$ & $83,13 \%$ \\
\hline Peningkatan keseluruhan & $\mathbf{1 5 , 6 3 \%}$ & & \\
\hline
\end{tabular}

Sebagaimana ditunjukkan pada tabel terjadi peningkatan hasil aktivitas belajar siswa dari siklus I ke siklus II. Hal ini menunjukan bahwa keterampilan membaca siswa dengan media kartu kata dapat meningkatkan aktivitas belajar siswa kelas I di 
UPT. SD Negeri 04 Baringin Kecamatan Lima Kaum Kabupaten Tanah Datar selama proses pembelajaran. Adapun persentase hasil aktivitas belajar siswa pada siklus I dan siklus II disajikan pada diagram berikut: Diagram Persentase Aktifitas Belajar Siswa Dengan Media Kartu Kata.

Sedangkan hasil observasi keterampilan mengajar guru yang diperoleh pada penelitian ini adalah sebagai berikut:

Tabel Persentase Aktivitas Mengajar Guru dengan Media Kartu Kata

\begin{tabular}{|c|c|c|c|}
\hline Skor & Pertemuan 1 & Pertemuan 2 & Rata - rata \\
\hline Siklus I & $63,75 \%$ & $78,75 \%$ & $71,25 \%$ \\
\hline Siklus II & $83,75 \%$ & $91,25 \%$ & $87,50 \%$ \\
\hline Peningkatan keseluruhan & $\mathbf{1 6 , 2 5 \%}$ & & \\
\hline
\end{tabular}

Sebagaimana ditunjukkan pada tabel terjadi peningkatan aktivitas mengajar guru dari siklus I ke siklus II. Hal ini menunjukan bahwa guru mengalami perbaikan dalam menciptakan kegiatan pembelajaran keterampilan membaca siswa dengan menggunakan media kartu kata sebagai upaya untuk meningkatkan keterampilan mebaca siswa kelas I di UPT. SD Negeri 04 Baringin Kecamatan Lima Kaum Kabupaten Tanah Datar. Adapun persentase aktivitas mengajar guru pada siklus I, siklus II, dan siklus III disajikan pada diagram berikut: Diagram Persentase Aktifitas Mengajar Guru Dengan Media Kartu Kata

Tabel Nilai Evaluasi Rata - rata Membaca Siswa Kelas 1 Menggunakan Media Karti Kata

\begin{tabular}{|c|c|c|}
\hline Evaluasi & Nilai Rata-rata & Kriteria \\
\hline Pra Siklus & 63.86 & Belum mencapai KKM \\
\hline Siklus I & 71,01 & Belum mencapai KKM \\
\hline Siklus II & 82,70 & Sudah mencapai KKM \\
\hline
\end{tabular}

Sebagaimana ditunjukkan pada tabel dapat dilihat adanya peningakatan nilai ratarata siswa dari rata-rata prasiklus, siklus I ke siklus II dengan peningkatan skor sebesar 5,21 (rata-rata prasiklus ke siklus 1) dan 7,79 (siklus 1 ke siklus 2) Peningkatan hasil tes evaluasi ini menunjukan tercapainya indikator keberhasilan. Diagram Rata-rata Hasil Keterampilan Membaca.

\section{Penutup}

Berdasarkan pelaksanaan penelitian tindakan kelas yang telah dilakukan dapat disimpulkan bahwa pembelajaran membaca permulaan dengan media kartu kata dapat meningkatkan keterampilan membaca pada siswa kelas I UPT. SD Negeri 04 Baringin Kecamatan Lima Kaum Kabupaten Tanah Datar, dapat dilihat pada setiap siklus: 1) Pada pra siklus nilai rata-rata keterampilan membaca siswa sebesar 63,86 dengan kategori rendah, dan hanya 15 siswa yang sudah bisa membaca dan masih ada 20 siswa yang belum bisa membaca. Dan setelah dilakukan tindakan siklus I nilai keterampilan membaca siswa naik menjadi 71.01 dengan kategori kurang walaupun belum memenuhi KKM, dengan jumlah siswa yang tuntas 20 siswa, siswa yang belum tuntas sebanyak 15 siswa. Dan keterampilan membaca siswa ada peningkatan pada siklus II dengan nilai rata-rata 87,20 dengan kategori baik sudah memenuhi KKM, dengan jumlah siswa yang tuntas sebanyak 32 siswa, dan siswa yang belum tuntas sebanyak 3 siswa; 2) Adapun dampak positif dari pembelajaran membaca permulaan dengan 
media kartu kata dengan ejaan suku kata dapat memudahkan siswa dalam membaca, penggunaan warna yang bervariasi pada kartu kata dapat menarik minat siswa dalam belajar membaca, dan penggunaan kartu kata yang melibatkan siswa secara langsung dapat memudahkan siswa dalam membaca dengan benar.

\section{Daftar Pustaka}

Abbas, Saleh. 2006. Pembelajaran Bahasa Indonesia Yang Efektif Disekolah Dasar.

Jakarta: departemen pendidikan nasional dierktorat jendral pendidikan tinggi direktorat ketenagaan.

Abdurrahman, Mulyono. 2003. Pendidikan bagi Anak Berkesulitan Belajar.Jakarta: Rineka Cipta

Akhadiah, Sabarti dkk. 1993. Pembinaan kemampuan Menulis Bahasa Indonesia. Jakarta: Erlangga.

Azhar Arsyad. (2006). Media Pembelajaran. Jakarta: PT Raja Grafindo Persada.

Budiasih dan Darmiyati Zuchdi. (2001). Pendidikan Bahasa dan Sastra Indonesia di Kelas Rendah. Yogyakarta: PAS.

Budi Rahman, Haryanto. (2014). Peningkatan Keterampilan Membaca Permulaan Melalui Media Flashcard Pada Siswa Kelas 1 SDN Bajayau Tengah 2: Jurnal Prima Edukasia, Vol. 2 No. 2.

Depdiknas. (2006). Peraturan Menteri Pendidikan Nasional RI No. 22 Tahun 2006 tentang Standar Isi Satuan Pendidikan Dasar dan Menengah. Jakarta: Depdiknas.

Dimyati dan Mudjiono. (2001), Belajar dan Pembelajaran. Jakarta: Rineka Cipta.

Iskandar (2012).Penelitian Tindakan Kelas. Jakarta: Gaung Persada Group.

Istanto, Budi .(2014). Peningkatan Keterampilan Membaca Permulaan Dengan Menggunakan Kartu Kata Pada Siswa Kelas 1 SD Negeri 1 Padeyan Jatinom Klaten. Fakultas Ilmu Pendidikan, Universitas Negeri Yogyakarta.

Miarso, Yusufhadi. (2007). Menyemai Benih Teknologi Pendidikan.Jakarta : Kencana.

Rahim Farida.(2005). Dasar Pengajaran Membaca di Sekolah. Jakarta: Bumi Aksara.

Sadiman Arief S. (2009) . Media Pendidikan. Jakarta: PT. Raja Grafindo Persada.

Sanjaya, Wina. (2010). Strategi Pembelajaran Berorientasi Standar Proses Pendidikan. Jakarta : Prenada Media Group

Sudjana, Nana. 2009. Dasar-Dasar Proses Belajar Mengajar. Bandung: Sinar

Baru Algensido

Sugiyono, (2013). Metode penelitian kuantitatif kualitatif dan R\&D. Bandung : Alfabeta

Suharsimi Arikunto dkk.(2005). Penelitian Tindakan Kelas. Jakarta: Bumi Aksara.

.........................(2012). Penelitian Tindakan Kelas. Jakarta: Bumi Aksara.

Trianto.(2010) Model Pembelajaran Terpadu. Jakarta: Bumi Aksara.

Undang-Undang Republik Indonesia Nomor 20 Tahun 2003 Tentang Sistem Pendidikan Nasional Bab 1 Pasal1 Ayat (1). 